\title{
Teachers' Individual Practical Knowledge about Teaching Reading Comprehension
}

\author{
Ramin Rahmany \\ Islamic Azad University, Takestan Branch, Iran \\ Mohammad Taghi Hassani \\ Imam Hossein University, Tehran, Iran \\ Hamid Fattahi \\ Islamic Azad University, Takestan Branch, Iran
}

\begin{abstract}
The present study was conducted to study language teachers' practical knowledge about the teaching of reading comprehension to engineering major students. The participants were 36 master and doctoral holders teaching ESP courses chosen from Payame Noor Universities of Kermanshah, Islamic Azad Universities of Kermanshah and Razi University of Kermanshah. A questionnaire was administrated to the participants. The first part of this study tried to search for any shared category(s) among the categories of practical knowledge and isolated the unshared category(s). The second part examined the overall unshared category(s) in order to see whether there is a significant difference among them or not. The study didn't detect any shared category but there was a significant difference in the categories.
\end{abstract}

Index Terms - language teachers' practical knowledge, teaching and reading comprehension

\section{INTRODUCTION}

In the last few decades, researches on teaching mostly focused on cognition and belief that underlies teachers' classroom practice, rather than their behaviors (Beijaard, Verloop \& Vermunt, 2000). This change in focus was mainly due to development in cognitive psychology, which was based on the fundamental assumption that one's cognitions and actions influences each other and, likewise, that teachers' cognitions and their classroom behavior mutually affect each other (Meijer, Verloop\&Beijard, 1999; Beijard, Verloop \& Vermunt, 2000). In many educational contexts, teachers were considered as executors who were supposed to implement new educational innovations designed by the researchers. But the majority of the innovations failed after a while and teachers relinquish the new behavior and returned to the old ways after a period of change (Verloop, Driel\& Meijer, 2001). As a result, researchers considered the centrality of teachers in education. If any of the new innovations hadn't corresponded with of the teachers' knowledge and belief, the failure would have happened.

According to Fenstermacher (1994), there's not always congruence between the knowledge that the teachers obtain during their education and the knowledge acquire through experience. Therefore, he discriminated two types of knowledge in the teachers, formal knowledge and practical knowledge the former is a knowledge that is known and made up by the researchers while the latter is a knowledge that is known and made up by the teachers themselves. To create professional practical knowledge the teachers need both kinds of knowledge. Formal knowledge is helpful to gain necessary knowledge for teaching and educational contexts provides insights, helps on the formation of explicit practical knowledge (Borg, 2003). In this study, the focus of attention is on what he refers to as teachers' practical knowledge.

Researchers have studied teachers' practical knowledge with various assumptions for different purposes. From a review of the studies on the teachers' practical knowledge, several characteristics have been identified: a) it is personal, which means it's somehow unique (Clandinin, 1986); b) it's content related meaning it's related to the subject being taught (Shulman,1986); c) it's context related which is based on classroom situation (Leinhardt, 1988); d) It's tacit which means teachers do not articulate their knowledge conspicuously (Meijer, Verloop \& Beijaard, 1999)

\section{LITERATURE REVIEW}

\section{A. Teacher Knowledge}

Knowledge is a familiarity about a subject which is acquired through education or experience which is explicit and universally and objectively true. (Woods \& Cadir, 2011). When we're talking about knowledge, It is mostly about the teachers' knowledge of their own professional identity i.e., how they perceive themselves as teachers. In this view, teachers are described in terms of an either subject matter expert, pedagogical expert, or a didactical expert (Beijarrd, Verloop and Vermunt, 2000). Lin (2005) identified three major ways that researchers in general and in language 
education have approached teacher knowledge: (1) categorization of teacher knowledge, (2) "explication of sources for teacher knowledge", and (3) investigation of the impact of teacher knowledge on teaching. He believed that these three areas are not independent are often combined in a single study. According to Fenstermacher (1994), there are four fundamental questions led some approaches to the topic of teachers' knowledge.

1. What is known about effective teaching?

Fenstermacher (1994) state that the answer to this question allows the researchers to address the concept of knowledge as it appears in standard or conventional behavioral science research. The concept of knowledge is called Formal knowledge. Based on his argument, researchers in this category do not see themselves as studying teacher knowledge so much as they perceive themselves producing knowledge about teaching. They seek the factors of good (successful, effective) teaching and if the methods and designs are in agreement with accepted scientific theory and principles, their results may be accepted as knowledge about teachers and teaching.

2. What do teachers know?

Based on Fenstermacher (1994) answering this question helps the researchers to understand what teachers know based on their teaching situation and context. The kind of knowledge is suggested in answering to this question is practical knowledge.

3. What knowledge is essential for teaching?

According to Fenstermacher (1994) this question seeks for the" forms "and "types of knowledge" required for teaching. Schulman (1986) describes two important arguments related to those issues. He starts his first argument about the origin and content knowledge base of teaching and draws some categories of knowledge required for teaching. In his second argument he introduces the notion of pedagogical content knowledge and focuses upon a few of the categories dealing with content and pedagogical knowledge, arguing that these are not nearly so well understood as the other categories of knowledge.

4. Who produces knowledge about teaching?

The answer to this question allows the researchers to address the difference between knowledge generated by university-based researchers and that generated by practicing teachers (Fenstermacher, 1994).

Day (1993) draws a continuum and discusses the types of activities by which, the student teachers can form either the declarative knowledge (at left end of the continuum) or the procedural knowledge (at the right end of the continuum) of teaching profession. As it defined by MacDonald, Badger, \& White (2001) declarative knowledge is knowledge about teaching- knowledge of subject areas and the 'theory' of education and procedural knowledge is knowledge of how to teach- knowledge of instructional routines to be used in the classroom. There are variety of activities between declarative knowledge and procedural knowledge which depending on their position, allow the learner to develop knowledge closer to one end or the other. The continuum is explained as follows:

1) Teaching 2) Micro-teaching 3) Observation 4) Simulation 5) Role-play 6) Discussion 7) Studying

B. Categories of Teachers' Knowledge

There are different categorizations of teachers' knowledge in different papers which are described as follows.

A) Elbaz (1983)

1) Self

2) The milieu of teaching

3) The subject matter

4) Curriculum development

5) Instruction

B) Grossmann (1990)

1) General pedagogical knowledge

2) Subject matter knowledge

3) Pedagogical content knowledge

4) Knowledge of context

C) Ferguson (1997)

1) Knowledge of the culture of the discipline

2) Knowledge of the value of the different disciplines

3 ) Knowledge of the genres and discourse patterns

D) Lowe (2010)

1) Subject content, including history and ethics

2) Subject reasoning, methodology and skills

3) Subject relationship to other subjects

4) Language sub structures such as phonemics to discourse

5) Language skills

6) Teaching skills and knowledge

During the past several decades, scholarly consideration has emphasized on the concept of teachers' professional knowledge and a number of reform to rethink both the structure of teacher education in order to enhance teacher preparation process (Sandlin, Young, \& Karge, 1992; Schulman, 1987; Woods, 1996; Fenstermacher, 1994). Kremer- 
Hayon \& Zuzovsky (1995) stresses that professional knowledge is a basic element that good teacher educators need to guide their supervision behaviors, and a lack of this knowledge can lower their confidence in discharging their duties. Schulman (1987, cited in Lowe, 2010) adds that teachers must have at least three types of professional knowledge (professional knowledge): pedagogical knowledge content knowledge, and student knowledge. The sum of those three knowledge forms PCK which is described below.

\section{Teachers' Practical Knowledge}

The term practical knowledge was first introduced by Fenstermacher (1994) who described it as the knowledge of teachers in comparison with formal knowledge which is knowledge for teachers. Practical knowledge is the knowledge that teachers generate as a result of their teaching in educational context. This knowledge is formed in classroom situations and includes all the practical dilemmas that teachers face in performing purposeful actions. As it stated by him: "practical knowledge is the type of knowledge which bounded by the situation or context in which it arises, and it may or may not be capable of immediate expression in speech or writing. The teachers' is generally related to how to do things, or the right place and time to do them, or about how to see and interpret events related to one's action."(p.11)

Clandinin (1992) looks at this knowledge in any individual teacher and calls it personal practical knowledge "Personal practical knowledge is reflected in the person's background, in the person's present mind and body and in the person's future plans and actions. It is knowledge that reflects the individual's prior knowledge and acknowledges the contextual nature of that teacher's knowledge and It is a kind of knowledge formed by, situations"(pp.125-126).

Schon (1987) defined four characteristics of practical knowledge. Firstly, practical knowledge is "time bound". Secondly, practical knowledge is "situation specific" and does not translate easily to other, even in similar circumstances. Thirdly, practical knowledge is "personally compelling". While information acquired in a professional development seminar might be interesting, it will not cause the teacher to alter practice unless the specific problem addressed is one that teacher is currently facing in the classroom. Finally, practical knowledge is led toward action. Elbaz (1983) describes that practical knowledge is represented in practice in three ways: First as an issue related to practice, which are brief, clearly formulated statements of what to do or how to do it in a particular situation; second, as practical principles, more inclusive and less explicit formulations in which the teacher's purposes are more clearly evident ; and third, as images, which are defined as a brief, descriptive, and sometimes metaphoric statement which seems to capture some essential aspect of teachers' perception of themselves, their teaching, their situation in the classroom.

Meijer et.al (1999) defined practical knowledge as knowledge and ideas that makes teacher action and classified it into these categories:

1) Knowledge about subject matter (knowledge about a particular subject)

2) Knowledge about student (general knowledge about student)

3) Knowledge about student learning and understanding (knowledge about learning and understanding of particular subject)

4) Knowledge about purpose (goals and the importance of teaching a particular subject)

5) Knowledge about curriculum (texts and the material used to teach a specific subject)

6) Knowledge about instructional strategy (how to design and organize the lessons for the subject

Driel et.al (1998) categories practical knowledge as follows:

1) Knowledge of subject mat

2) Knowledge of general pedagogy;

3) Knowledge of student learning and conceptions;

4) Knowledge of purposes;

5) Knowledge of curriculum and media;

6) Knowledge of representations and strategies;

7) Knowledge of context

\section{OBJECTIVE OF THE STUDY}

The purpose of this study is to investigate teachers' individual practical knowledge about reading comprehension. The first part of this study searches for a shared category among the categories of practical knowledge and isolates the unshared parts. The second part examines the unshared parts in order to see whether the difference is significant or not.

\section{RESEARCH QUESTION}

Regarding the foregoing discussion, the study aims at answering the following research questions:

1. Do Iranian ESP teachers have any shared of practical knowledge

2. Is there any significant difference in the overall unshared categories of practical knowledge between ESP teachers holding master degree and doctoral degree? 


\section{A. Participants}

This study was started with 50 male and female Iranian university teachers having master and doctoral degree and teaching English for specific purpose (ESP) to students majoring in engineering .The teachers are chosen from Razi University of Kermanshah, Islamic Azad Universities of Kermanshah and Payame Noor Universities of Kermanshah. The initial number of participants was then reduced to 40 since not all participants participated in the experiment or had different proficiency level than other participants. 4 other participants were also since their proficiency level went much different than others. Finally 18 teachers who had master degree and 18 teachers who had doctoral degree were chosen in this study.

\section{B. Study Materials}

In the present study, the questionnaire was designed is utilized to collect data. There are 10 closed ended questions and they are designed based on the goal of the study and six systems of categories that are provided by Meijer et al (1999). For each of the closed-ended items, three choices are offered. Participants were required to choose the one that corresponded to their opinions.

\section{Procedure}

At first, the participants were informed about the purpose of the study. Then, the questionnaire was distributed among the participants via e-mail or in person with the help of some colleague's. Then the responses were collected and prepared for analysis.

\section{RESULTS}

\section{A. Investigation of the First Research Question}

The first research question sought to investigate the similarities and differences in teachers' individual practical knowledge and capture the shared category(s) of the practical knowledge. To answer this question a table 4.1 is drawn showing the number of their similar and different responses to each question.

TABLE 4.1.

DIVERSITY OF THE TEACHERS' RESPONSE TO THE QUESTIONS

\begin{tabular}{|l|l|l|l||}
\hline Category & $\begin{array}{l}\text { Question } \\
\text { number }\end{array}$ & Number of similar response & Number of different responses \\
\hline \multirow{2}{*}{ Subject Matter Knowledge } & 1 & 0 & 2 \\
\cline { 2 - 4 } & 2 & 0 & 2 \\
\hline \multirow{2}{*}{ Student Knowledge } & 7 & 0 & 2 \\
\cline { 2 - 4 } & 8 & 0 & 3 \\
\hline Knowledge of Student Learning and & 9 & 0 & 3 \\
\cline { 2 - 4 } Understanding & 10 & 0 & 2 \\
\hline Knowledge of Purpose & 5 & 0 & 2 \\
\cline { 2 - 4 } & 6 & 0 & 3 \\
\hline Knowledge of Curriculum & 3 & 0 & 3 \\
\hline Knowledge of Instructional Technique & 4 & 0 & \\
\hline
\end{tabular}

The results of the first part showed the teachers in this study did not have any shared practical knowledge. As it's seen, the great diversity exists in the category of knowledge of student learning and understanding (with three and four different responses) and low diversity in the following categories: subject matter knowledge and knowledge of purpose (with two different responses). Therefore, the first null hypothesis is supported and the teachers do not have any shared practical knowledge at all. Therefore, all the categories are considered as unshared and first must be analyzed individually

\section{B. Investigation of the Second Research Question}

The second research question attempts to see whether there is significant difference in the overall unshared categories of practical knowledge or not. To this end, first each category of practical knowledge must be studied individually. Each category must be analyzed in a term of having a significant difference in the responses to the question relating to that specific category. Finally the existence of significant difference in the entire categories of practical knowledge is investigated. The teachers' responses in a form of descriptive and inferential statistics in each category of practical knowledge are shown in the tables below.

TABLE 4.2

INDEPENDENT T-TEST FOR THE CATEGORIES OF PRACTICAL KNOWLEDGE

\begin{tabular}{|l|l|l|l|l|}
\hline Category & T & Df & P & Mean Difference \\
\hline Subject Matter Knowledge & 1.263 & 20 & 0.221 & .45000 \\
\hline Student Knowledge & 2.137 & 10.113 & 0.058 & 1.08654 \\
\hline
\end{tabular}




\begin{tabular}{|l|l|l|l|l|}
\hline $\begin{array}{l}\text { Knowledge of Student Learning and } \\
\text { Understanding }\end{array}$ & .376 & 17 & 0.712 & .27778 \\
\hline Knowledge of Purpose & 2.157 & 23 & .040 & .53247 \\
\hline Knowledge of Curriculum & 2.229 & 10.574 & .049 & .675 \\
\hline Knowledge of Instructional Technique & 1.796 & 23 & .086 & .35056 \\
\hline
\end{tabular}

According to the table 4.1, the value of "p" is above the significant level in the Subject Matter Knowledge, Student Knowledge, Knowledge of Student Learning and Understanding and Knowledge of Instructional technique categories. Therefore, It can be argued that the difference is not significant on those categories. On the other hand, The value of "p" is below the significant level in the Knowledge of Purpose and Knowledge of Curriculum categories. So, It can be argued that there is a significant difference between the two groups of teachers on those two categories.

\section{Investigation of the Overall Categories of Practical Knowledge}

TABLE 4.3

ONE SAMPLE T-TEST FOR THE OVERALL CATEGORIES OF PRACTICAL KNOWLEDGE

\begin{tabular}{|l|l|l|l|l|}
\hline Mean Difference & $\mathrm{P}$ & $\mathrm{Df}$ & $\mathrm{T}$ & Value \\
\hline .60000 & .024 & 9 & 2.714 & Differences \\
\hline
\end{tabular}

According to Table 4.3, since the value of "p" is statistically significant (=.024), we can safely claim that there is significant difference between the means of the groups. So, the second null hypothesis developed in chapter one is rejected. The reason for this significant difference is mostly due to difference in the Knowledge of Purpose Category and Knowledge of Curriculum Category. Based on the results, we can argue that the master holding teachers emphasized more on Knowledge of Purpose and Knowledge of Curriculum category than doctoral holding teachers.

Although the aim of this study was not to evaluate teachers' practical knowledge in order to establish knowledge base for teaching, some researchers (Verloop et.al; Beijaard et.al; Rosnidar et.al; Ajideh, 2003; Clemente et.al, 2008; Driel et.al; Fenstermacher, 1994; Gatbonton 2008; Miranda, 2008; Reynolds, 1989) focused on establishing the knowledge base for teachers which serves as a guideline for their teaching. They believed that knowledge base not only helps teachers to improve their status of teaching profession but also serves as a guideline in educating new teachers.

\section{DISCUSSIONS AND CONCLUSIONS}

The result of the first part of experiment showed the Knowledge of Student Learning and Understanding category has the greatest diversity in the responses and the Student Knowledge and Knowledge of Purpose has the lowest diversity in the responses. The results of the second part of the experiment revealed that there is a significant difference in overall categories of practical knowledge. The significant difference is mostly due to the significant difference in the Knowledge of Purpose and Knowledge of Curriculum category. The teachers in this study tended to reflect on their teaching in a way that maintained the focus of their practical knowledge. For example, teachers who focusing on subject matter category in their practical knowledge tended to think that subject matter are an important issue in their teaching. Similarly, teachers who focused on student knowledge category believe that the knowledge of students (age, sex, level, major, personality, etc) should be taken into account prior teaching. They see the problematic situations are due to teachers' lack of enough knowledge about students. Likewise the teachers focusing on the student learning and understanding category are always looking for ways to improve teaching based on students learning a student-learningoriented teacher,

As the result of the second part showed, there was a significant difference among all unshared categories of practical knowledge. By comparing the results of the first part and the second part, we saw that the significant difference is not in the category that has the greatest number of different responses. Therefore, we can conclude that the existence of a significant difference depends on another factor as well in addition to numbers of different response. Another factor that affect on the results is number of the teachers who agreed or disagreed on the specific category, in another word, concentration of responses in each specific choice. The master holding teachers in our study in contrast to the doctoral holding teachers had had different emphasis on different categories of practical knowledge. According to the results of the second part, we can assert the master holding teachers focused more on Knowledge of Purpose and Knowledge of Curriculum category than doctoral holding teachers, since their mean is much higher. The reason for this difference might be due to the fact that the master holding degree teachers tend to be more conservative than doctoral holding teachers. They focus mostly on the required textbook and the given syllabus and try to follow the syllabus exactly as written. On the other hand, the doctoral holding teachers do not mostly like follow the given syllabus exactly as stated. They prefer to design their own teaching material than the materials required by authorities such as textbook. They also don't focus on final exam as much as the master holding teachers do.

Based on the results of both parts we can conclude that continuing education has considerable effect on the practical knowledge and higher education seems to change the view and approach of the teachers toward teaching different subject. In addition to the aforementioned reason, there might be some other reasons the second reason can be due to the differences in their context of teaching. In some contexts the teachers must follow a specific syllabus for teaching 
whereas in some other contexts the teachers don't feel such pressure on themselves. The third reason might be due to their difference in the number of teaching experience which might affect on their view and approach toward teaching.

In this study one important question arises? The question is whether this variety of practical knowledge is acceptable or not. Teachers who seem to have limited practical knowledge rarely think about their teaching profession and so lack good understanding about what is happening in their classroom environment or in their students mind. Some teachers might not find the categories of their practical knowledge useful for clarifying their practical knowledge because most of the teachers might not have thought about some categories explicitly.

\section{IMPLICATIONS}

The findings of the present study can have implications not only for teachers and learners but also for syllabus designers. The selection and implementation of the appropriate syllabus can have a considerable effect on improving and teaching reading skill. According to this study, if syllabus designers and teachers consider all the issues in the practical knowledge, they will be able to prepare textbooks in a way which can facilitate reading comprehension.

\section{SUGGESTIONS FOR FURTHER RESEARCH}

In this article, the relationship between a teachers practical knowledge their teaching method was not the focused. Further research can also be carried out to investigate this issue. Another issue that can be investigated is whether teachers practical knowledge affects on the learning process of the learners and one might find a relationship between those two variables.

\section{APPENDIX A. QUESTIONNAIRE}

Name:

Sex:

Age:

Teaching experience (how many years):

Degree Level: Master Doctoral

Direction: There are 10 questions in this questionnaire. For most of the questions, different choices are offered. Please tick the one that corresponds to your opinion or if you're receiving this questionnaire by e-mail, highlight (bold) the best answer. If you have different suggestions, you are welcome to write them down in the last choice of each item.

1. What is reading comprehension?

A) to understand the essence of a text

B) to relate the content of the text to the real world

C) to have insight into the content of a text

D) to have insight into the structure of a text

2. What is the relationship of reading comprehension to other language skills?

(speaking, listening, writing, and translating)?
A) reading is a separate skill basically unrelated to other skills
B) reading is not a separate skill from other language skills
C) reading is the basis of all the other language skills
D)reading is the least important skill among language skills.

3 . What kinds of materials/texts do you use in the lessons on reading? comprehension?
A) only the material from textbooks
B) prefer to use texts focused on the final exams
C) prefer to select my own texts, from newspaper or elsewhere
D) both the material from textbooks and some other materials, like newspaper

4. How to design your lessons?
A) prepare lessons in detail, design them according to the textbooks I am using
B) not to prepare lessons, design them as function of questions, reactions and moods of the students
C) although prepare lessons in detail, sometimes make slight changes
D) sometimes prepare lessons in detail, sometimes not (as choice B presents)

5. Why is reading important?
A) reading is the most important part in learning English
B) reading is the most important part in the exams
C) reading is important in conveying and understanding messages
D)reading is important for improving other language skills(vocabulary, speaking, and writing)

6. What are the goals in teaching reading?

A) to expand students' vocabulary 
B) to get higher scores in the exams

C) to enhance students' reading abilities

D)to improve reading as well as other language skills(vocabulary, speaking, writing)

7. Do you know the characteristics of your students?
A) Yes, I know exactly who they are
B) Yes, I have some ideas about my students
C) I have some ideas about some students, not all of them
D) No, I do not know

8. How about the motivation of students in your class?
A) they have strong motivations
B) they need to be motivated sometimes
C) they always need to be motivated
D) they do not like the course at all

9. What do students consider the most difficult when reading a text in your opinion?
A) too many words they are not familiar with
B) hard to work up concentration on reading
C) not familiar with the texts and they are uninteresting and unreadable
D) have problems with the structure of a text and how it is put together

10. Students' reading abilities are different. What do you think is the most important factor for it?
A) students' talent and self-confidence
B) students' reading strategies
C) students' reading level or reading skills
D) students' practice and hard-work

\section{ACKNOWLEDGEMENT}

First and foremost, I am grateful to my thesis committee, Dr.Bahador Sadeghi, Dr.Ramin Rahmany, Dr Mohammad Taghi Hassani and Dr. Abbas Ali Zarei, , who contributed to this research. My best regards go to my supervisor, Dr.Rahmany, for his support, guidance, suggestions, tolerance, motivation and kind assistance as well as his brilliant advice and comments throughout the research. My gratitude is also expressed to my advisor Dr Mohammad Taghi Hassani for his remarkable suggestions. I am also thankful to Dr. Sadeghi, the Head of the English Department, for his constant support.

I would like to offer my special thanks to my parents and all those who have helped and supported me during the research. Last but not least, I would like to express my deepest gratitude to my family, who provided me with the warmest support and unconditioned love, care, patience, guidance, and good will.

\section{REFERENCES}

[1] Beijaard, D., \& Verloop, N., \& Vermunt, J. D. (2000). Teachers' perceptions of professional identity: An exploratory study from a personal knowledge perspective. Teaching and Teacher Education, 16, 749-764.

[2] Borg, S. (2003). Teacher cognition in language teaching: A review of research on what language teachers think, know, believe and do. Journal of Language teaching,36, 81-109

[3] Clandinin, D.J. (1986). Classroom practice: ${ }^{1}$ eacher images in action. London: Falmer

[4] Clandinin, D. J. (1992). Narrative and story in teacher education. London: Falmer Press.

[5] Clemente, M., \& Ramirez, E. (2008). How teachers express their knowledge through narrative. Teaching and teacher education, $24,1244-1258$.

[6] Day, R. (1993). Models and the knowledge base of second language teacher education. University of Hawai'i Working Papers in ESL, 11(2), 1-13.

[7] Elbaz, F (1983). Teacher thinking: a study of practical knowledge. London: Croom Helm

[8] Fenstermacher, G. D. (1994). The knower and known: The nature of knowledge in research on teaching. Review of Research in Education, 20, 3-56

[9] Ferguson, G. (1997). Teacher education and LSP: The role of specialized knowledge Clevedon: Multilingual Matters.

[10] Gatbonton, E. (2008). Looking beyond teachers' classroom behavior: Novice and experienced ESL teachers' pedagogical knowledge. Language Teaching Research 12,2,161-182.

[11] Hosenfeld, C. (1984). Case Studies of Ninth Grade Readers. New York: Longman

[12] Kremer-Hayon, L. and Zuzovsky, R. (1995). Themes, processes and trends in the professional development of teacher educators. London: The Falmer Press.

[13] Leinhardt, G. (1988). Situated knowledge and expertise in teaching. London: Falmer.

[14] Lin, F. A. (2005). Knowledge Base of English as a Second Language Teacher. Dissertation Abstracts International, 1, 1-47.

[15] Lowe,I. (2010). ESP teachers MUST teach specialist content. Review of educational research, 1, 1-10.

[16] MacDonald, M., Badger, R., \&White, G. (2001). Changing values: what use are theories of language learning and teaching. Teaching and Teacher Education, 17(1), 949-963.

[17] Meijer, P.C., Verloop, N., \& Beijaard, D. (1999). Exploring language teachers' practical knowledge about teaching reading comprehension. Teaching and Teacher education, 15 (1),59-84. 
[18] Reynolds, M. C. (Ed.). (1989). The knowledge base for the beginning teacher. Oxford: Pergamon Press.

[19] Rosnidar, R., Lilia, H., \& Kamisah, O. (2010). Teachers' knowledge that promotes students' conceptual understanding. Procedia Social and Behavioral Sciences, 9,1835-1839.

[20] Sandlin, P., Young, C.D \& Karge. (1992). The theory of knowledge. New York: Macmillan.

[21] Schon, D. (1987). Educating the reflective practitioner, Jossey-Bass, San Francisco.

[22] Shulman, L.S. (1986). Those who understand: Knowledge growth in teaching. Educational Researcher, 15(2), 4-14.

[23] Verloop, N., Driel, J. V., \& Meijer, P. C. (2001). Teacher knowledge and the knowledge base of teaching. Journal of Educational Research, 35, 441-461.

[24] Woods, D. (1996). Teacher cognition in language teaching. Cambridge: CUP.

[25] Woods, D., \& Cakir, H. (2011). Two dimensions of teacher knowledge: The case of communicative language teaching. System, $39,381-390$

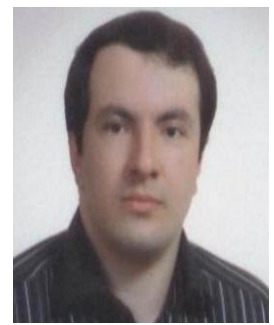

Ramin Rahmany is a Ph.D. holder of teaching English as a foreign language from Tehran University, Iran. Currently, he is an assistant professor in Azad University of Takestan, Iran.

His major interests are language and acquisition, computer assisted language learning, and psycholinguistics. He has taught several courses at university like Language methodology and discourse analysis.

He has published several articles in language learning acquisitions e.g. Acquisition of English Relative Clauses by Persian EFL Learners published by Journal of Language and Linguistic Studies in October 2009.

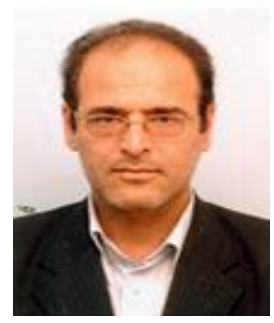

Mohammad Taghi Hassani assistant professor in TEFL at Imam Hossein University, Tehran and Islamic Azad University, Takestan Branch, Iran. His research interests are EFL writing, psycholinguistics, phonetics, contrastive analysis, English for Specific Purposes, and language teaching methodology.

He has published several articles in language teaching and learning e.g. The effect of Self Assessment on Iranian EFL learners' writing skill, published by Iranian EFL Journal in October 2012.

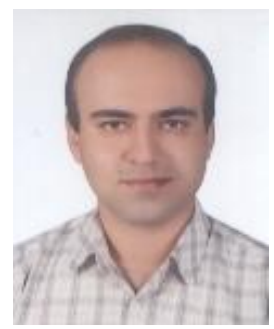

Hamid Fattahi was born in Kermanshah, Iran. He's presently an M.A student in TEFL at Islamic Azad University of Takestan, Ghazvin Iran. He received his BA from Razi university of Kermanshah in 2008.

He has over 5 years of teaching experiences at different language institutes. He's currently an English teacher at Islamic Azad Universities in the province Kermanshah. His research interests lie in ESP, reading strategies, teacher education and evaluation. 